http://jmscr.igmpublication.org/home/ ISSN (e)-2347-176x ISSN (p) 2455-0450 crossref DOI: https://dx.doi.org/10.18535/jmscr/v9i8.27

\author{
(D) Journal Of Medical Science And Clinical Research \\ IGM Publication \\ An official Publication of IGM Publication
}

\title{
Impact of Covid-19 and Information Technology as a helping hand to fight Pandemic
}

\author{
Author \\ Vandana Malik ${ }^{1}$ \\ ${ }^{1}$ Ph.D. scholar, Department of Computer Science Himachal Pradesh University, Shimla
}

First case of COVID-19 surfaced in China in December 2019 and three months later The World Health Organization declared COVID-19 as pandemic on March 11, 2020. Complete lockdown was necessary Total covid-19 cases since then there have their jobs and businesses etc. Amides of all this chaotic situation information technology has played major role in all aspects of life. Impact of pandemic on Socio-economic conditions of people, change in behavior and cultural practices can be observed. During complete lockdown in 2020 people used internet and information technology from getting health facility to groceries. Technology has been boon to mankind and a helping hand in defeating COVID$19^{[2]}$

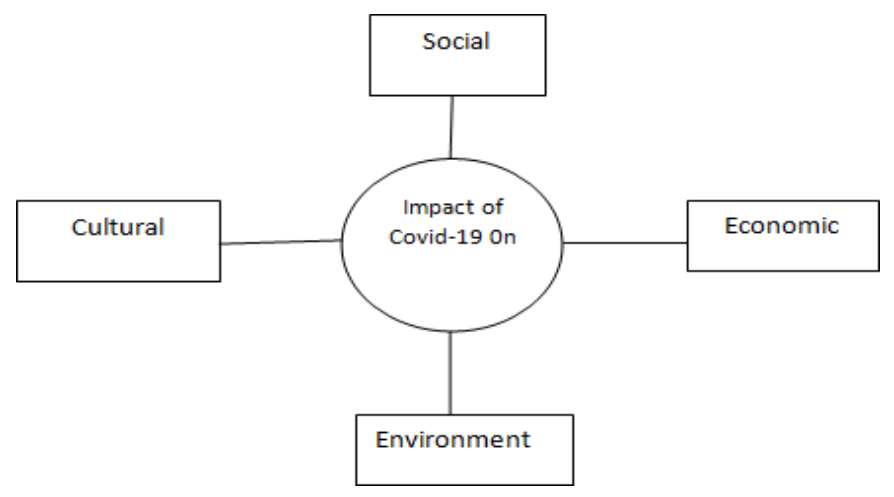

Social

Impact of Covid-19 can be seen on every section of society.
Senior citizens are the most affected as they have week immunity and co morbidities which make them vulnerable and their mortality rate is high. According to WHO $95 \%$ of death due to covid-19 is of people above 60 years of age ${ }^{[3]}$.

Impact of covid-19 on women can be clearly seen as many women working in unorganized sectors lost their jobs. During lockdown household work, care work with limited finance has amplified their problems. Women are facing issues of domestic violence, inequality, early marriage and dropping out of school and colleges. According to UN report pandemic will push 96 million people into extreme poverty and out of which 47 million are women and girls living on USD1.90 or less $^{[4]}$.

$\square$ Impact of Covd-19 on children, since 2020 schools and colleges are closed and education is being imparted online. Weaker sections of society who are unable to access internet, who have limited resources are being left behind even though free and compulsory education to children from 6 to 14 years of age is a fundamental right under the Article 21A. Digital inequalities, gender biasness and digital divide is increasing day by day ${ }^{[5]}$.. 
Exams are not being conducted which is again hampering the career prospects of many aspirants. Children are online for long time which impacts their physical and mental health. 6 to 7 million children below 5 years of age are suffering malnutrition, wasting and stunting due to poverty ${ }^{[6]}$.

\section{Economy}

$\square$ Due to pandemic and lockdown businesses like tourism and hospitality has suffered alot.

$\square$ Supply Chain was broken as international borders were closed no import or export waspossible

$\square$ Petrol prices in 2020 went down drastically because of lockdown there was restriction on movement and people did not travel therefore demand of petrol was less. Middle East countries major export of natural gas and crude oil faced economic crisis during pandemic $^{[7]}$.

$\square$ Millions of people lost their jobs.

$\square$ Migration of people from urban areas to rural areas was heart breaking event to see. Where people walked for $300 \mathrm{Km}$ to reach their native places. Migrants were potential carrier of disease to rural areas ${ }^{[8.1]}$.

$\square$ Agriculture sector faced shortage of labors during harvesting and sowing season. Farmers switched towards cotton from rice cultivation because of it being labor intensive. It could have affected our food security ${ }^{[8.2]}$.

Manufacturing sector also faced a major blow as demand of products decreased and factories were closed. Positive growth was seenin pharmaceutical and medical equipment industries when India tried to manufacture PPE kits (personal protective equipment) and vaccination for Covid-19 (Covishield and Covaxin). India had failed to anticipate the arrival of second wave which disrupted the delivery of vaccines to foreign countries. As very small population of India was vaccinated when the second wave of Covid-19 hit India and all the resources where directed to meet the domestic needs for vaccines, oxygen, ventilators, medicine and PPE kits. ${ }^{[9]}$

$\square$ Maximum use of online payment mode was observed because currency notes and coins were considered as virus carries so termed as dirty money. People preferred safe and secure online payment methods. ${ }^{[10]}$

\section{Culture}

$\square$ Covid-19 has changed the way people greet and meet each other with elbow bumps instead of handshakes. People are using elbow bumps at workplace, politicians uses elbow bumps to depict the way we can prevent virus from spreading and it is a constant reminder of following Covid-19 appropriate behavior. $^{[11]}$

$\square$ Big fat Indian wedding turned into private and small parties because huge gathering acts like super spreading events.

$\square$ Trami -Centuries old Kashmiri tradition of eating food from one plate in wedding is not being followed due toCovid-19. ${ }^{[8.3]}$

$\square$ Temples, mosques, churches were closed for public gathering,prayers. ${ }^{[12]}$

$\square$ Festivals celebrations were allowed but only in home premises without huge gathering in a peaceful manner. ${ }^{[13]}$

\section{Environment}

- Origin of Covid-19 is still unclear but many scientists believe that it has been transferred from animals to human. As human animal interaction has increased because of forest area converted into agricultural land and residential area. Humans have encroached into forest, animal habitat which used acts as buffer between humans and animals and forest used to contain and hold different types of viruses and bacteria's away from humans. Animal based diet, wild and exotic animal available in wet market of China as food, frozen contaminated food are considered some reasons for origin of the coronavirus. ${ }^{[14]}$

- Air quality improved during Lockdown all 
around the world as carbon and green house gas emission was limited. Delhi Pollution Drops by $49 \%$ During Lockdown and India's $\mathrm{CO} 2$ Emissions Fall for First Time in 40 Years $^{[15]}$

- Biodiversity was thriving with limited human interference during lockdown like Gangetic dolphins were found in Mahananda river of Bihar. As water pollution was less due to closed factories, sewage and untreated industrial waste was not contaminating the river water. ${ }^{[16]}$

- Negative impact of Covid-19 pandemic on environment is that lots of biomedical waste is generated which needs to be disposed properly so that it may not lead to contamination. Guidelines are provided by the government for proper disposal of biomedical waste. Plastic waste, glass waste from millions of vaccine doses manufactured, masks , gloves, face shield and PPE kit is hazardous to ours environment. ${ }^{[17]}$

\section{Information technology assisted us to fight Covid-19 in the following ways \\ Information dissemination: as SARS-COV-} 2 was a new virus and limited information was available therefore in order to provide correct and reliable information various online platforms were used. Social media was used to spread information and Covid-19 appropriate behavior. To spread awareness among masses internet has played a major role. $^{[2]}$

Policy Making: data analysis helps government take informed decision and build a strategy to deliver food, essential services to people during lockdown and maintained supply chain. ${ }^{[2]}$

$\square$ Onlinen Education: school and colleges were closed since March 2020 and 1.2 billion Children are out of classrooms. Students are studying online and teachers taking Classes on digital platform like Zoom, Google meet etc. Rise of edtech companies can be seen were education related videos; software and learning apps are being designed. ${ }^{[18]}$

$\square$ Virtual Reality: can help in improving learning experience and enhancing the content delivered to the children that can help them understand concepts better. It can help in Speech training, Skill enhancement in medical education can be done by gaining practical knowledge through experiencing real environment in 3D. Virtual field trips like exploring ocean depth, solar system and experience historical events for better understanding. ${ }^{[19]}$

$\square$ Aarogya setu: is a mobile application used for contact tracing of covid-19

COWIN app: registration for getting vaccinated for coronavirus.

Chat bot: government issued a number where people can get correct information and answer to their queries regarding coronavirus. $^{[20]}$

$\square$ Tele medicine: provide virtual healthcare to people living at remote location by using various communication methods so that everyone gets health care services. It also prevented spreading of viruses by avoiding mass gatherings at hospitals and in keeping medical staff safe from risk of getting exposed to virus. ${ }^{\text {[21] }}$

Mental and psychological health: covid-19 has impacted in number of ways during lockdown people were alone facing depression, financial crises, many lost their near and dear ones which disturbed them mentally and emotionally. Physical distancing, isolation is worsening the condition of elderly people. Many helpline numbers were started where people could discuss their problems and online sessions were conducted, counseling was provided. ${ }^{[22]}$

Work from home: IT Sector and many businesses shifted to online mode when pandemic started. It helped in breaking the chain of spreading corona virus. Work from home has become the new normal where 
people are in safe environment, running businesses, conducting meeting on various platforms and performing economic activities. Many IT employees went back to their native places, to small towns and working from their without any problem. People are working with flexible schedule, giving time to their family and are safe from corona virus. If companies allow their employees to work from any location post pandemic it will cut down the cost of infrastructure, transportation and maintenance. $^{\text {[23] }}$

Surveillance: Drones can help in providing security and surveillance. Robots can do screening of people by checking their temperature in public places and at airports. Drones will help in monitoring streets, disinfect contaminated places and help deliver medical supplies to remote locations. $^{[2]}$

3D Printing: help in making protective medical supplies like masks, face shields and surgical instruments, PPE kits, testing devices like nasopharyngel (NP) swabs, training and visualization aids like medical manikins and bio models etc. ${ }^{[24]}$

Research and Development: information technology helped scientists to collaborate, ICT helps in collecting data, sharing data, analyzing data and developing efficient results. ${ }^{[25]}$ Genome sequencing of SARSCOV-2 virus to study different variants and mutations taking place in them to upgrade our vaccines. $^{[26]}$

Rise of OTT platform: During pandemic people moved to OTT (over the top) platform for entertainment. Where they can watch movies, web series, online gaming etc of their own choice. It provided job opportunities to people when economic crunch. ${ }^{[27]}$

$\checkmark$ Social media: played a major role in connecting people to their friends and families during lockdown. It was a major source of information and a platform to spread awareness. ${ }^{[1]}$

$\square$ E-Courts: During pandemic supreme court and other high courts were providing justice by conducting proceeding online

$\square$ Digital Governance: governments are providing services which can be availed from anywhere by using internet and visiting official portals to get benefit of welfare scheme and it also ensures accountability and clear demarcation of work. It prevents corruption in government sector because of automation of tasks where people cannot work according to their whims and fancies. ${ }^{[2]}$

$\square$ Online Summits: governments and international organizations across the worlds are engaging through online platforms and cooperating with each other and developing relationships and strategies to curb coronavirus.

SAARC 2020, BRICS Summit 2020, G-20 Leaders' Summit 2020, Association of Southeast Asian Nation (ASEAN) 2021 were conducted virtually to discuss pandemic and other issues around the world. Virtual Aadi Mahostav in Madhy Pradesh was organized by ministry of tribal affairs in order to celebrate spirit of tribal culture, craft, cuisine and commerce.

$\square$ Online Campaigning: to avoid mass gathering and by following social distancing norms of pandemic election campaigns could be conducted online and politicians can connect to the citizens and ask for their votes by digital modes like social media.

E-Commerce: online shopping and grocery purchase have increased during pandemic. New online businesses have started growing and providing employment to people. Providing people with all the necessary thing at home in order to keep themindoors.

\section{Limitation of Information technology}

Privacy and Security Issues: data on digital platforms is not secure it can be hacked, accessed by unauthorized users, data manipulation can 
take place. Recently we have seen many cases of malware, ransom ware which affect businesses. Mobile application takes personal information which helps in contract tracing and potential risk of getting exposed to get covid-19 but this information can be misused. Cybercrimes, scams, phishing attacks have increased Zoom data leak, solar wind hack cyber attack on US government. $^{[28]}$

Digital divide: Pandemic has highlighted the inequalities that exist in our society where may people are not yet ready to embrace technology and are lacking behind because they cannot afford it. Online education in rural India is difficult because of limited resources and limited access to the internet. Senior citizens are unable to get along with technology therefore left behind. Gap between digital have and have not's needs to be reduced by providing children with ICT devices and internet access so that children can continue studying and learning while schools are closed because of pandemic. ${ }^{[29]}$

Fake News: As internet is available to all and social media was used to spread fake news and misinformation during pandemic and people trying to cure disease at home with remedies seen online which may not produce positive result. Cases of spreading misinformation about vaccines developed against corona virus were seen. Fake news and distortion of information can put people at risk and losing their lives. ${ }^{[30]}$ Deep fakes: manipulated images videos and audios circulate around to build perception and influence people.

Children are online for many hours which is impacting their health condition and it's difficult to keep track of their online activities. Children face cyber bullying which cause psychological issues.

We should be wise and responsible while dealing with technology as it is a double edged sword. India needs to build its infrastructure and capacity in order to provide benefit of technology to the last person in the last village. People need to learn and increase digital literacy in order to get maximum benefits. India needs data protection and localization laws to secure data of its citizens. As ICT have helped mankind and promoted ease of living. Therefore we can say a friend in need is a friend in deed and technology has proven to be our friend and a helping hand at the time of crises. By continuous research and development we can keep evolving and improving our heath infrastructure and technology which will enable us to defeat corona virus.

\section{References}

1. https://covid19.who.int/

2. https://www.un.org/development/desa/dp ad/publication/un-desa-policy-brief-61covid-19-embracing-digital-governmentduring-the-pandemic-and-beyond/

3. https://www.medicalnewstoday.com/artic les/the-impact-of-the-covid-19-pandemicon-older-adults\#Old-age-and-preexistinghealth-conditions

4. https://www.unwomen.org/en/news/storie s/2020/9/feature-covid-19-economicimpacts-on-women

5. https://www.weforum.org/agenda/2020/1 0/how-covid-19-deepens-the-digitaleducation-divide-in-india/

6. https://www.unicef.org/coronavirus/COV ID-19-pandemic-scarred-world-children

7. https://www.worldbank.org/en/news/featu re/2020/06/08/the-global-economicoutlook- during-the-covid-19-pandemica-changed-world

8. [8.1]https://www.thehindu.com/news/nati onal/returning-migrants-a-threat-to-ruralareas- mha/article31446313.ece

[8.2]https://www.thehindu.com/news/nati onal/other-states/punjab-could-see-moreareas-under-cotton-

cultivation/article31440214.ece [8.3]

https://www.thehindu.com/news/national/ other-states/pandemic-puts-on-holdkashmiri-wedding-tradition-of-eating- 
together-from-oneplate/article32655494.ece

9. https://thewire.in/economy/the-impact-ofcovid-19-on-indias- manufacturingsector

10. https://www.ncbi.nlm.nih.gov/pmc/article s/PMC7280123/

11. https://abcnews.go.com/International/elbo w-bumps-handshake-amid-coronavirusoutbreak/story?id=69434364

12. https://www.newindianexpress.com/galler ies/nation/2020/mar/19/covid-19-impacthere-are- the-temples-in-india-that-havebeen-shut-down-102803.html

13. https://www.mentalhealth.org.uk/coronav irus/celebrating-festivals-and-occasionsduring- lockdown

14. https://abcnews.go.com/Health/covid-19virus-origin-animal-human-transmissionreport/story? $\mathrm{id}=76746997$

15. https://weather.com/enIN/india/pollution/news/2020-05-13delhi-pollution-drops-49-lockdown-indiaco2-emissions-40-years

16. https://www.downtoearth.org.in/news/wil dlife-biodiversity/gangetic-dolphinsfound-in-bihar-s-mahananda-river-65413

17. https://pib.gov.in/PressReleaseIframePag e.aspx?PRID=1657061

18. https://www.weforum.org/agenda/2020/0 4/coronavirus-education-global-covid19online-digital-learning/

19. https://vedx.io/how-can-virtual-realityimprove-the-learning-process/

20. https://www.moneycontrol.com/news/tec hnology/heres-a-list-of-apps-launchedby-centre-and-state-governments-totackle-covid-19-crisis-5106381.html

21. https://www.healthcareitnews.com/news/t elemedicine-during-covid-19-benefitslimitations-burdens-adaptation

22. https://www.euro.who.int/en/healthtopics/health-emergencies/coronaviruscovid-19/news/news/2020/3/mentalhealth-and-psychological-resilience- during-the-covid-19-pandemic

23. https://economictimes.indiatimes.com/ma gazines/panache/work-from-home-hasbeen-successful-during-covid-19-

lockdown-whatnext/articleshow/75470580.cms.

24. https://www.nature.com/articles/s41578020-00234-3

25. https://www.ukessays.com/essays/inform ation-technology/role-of-ict-in-researchinformation-technology-essay

26. https://www.peoplenewspapers.com/2021 /03/31/how-genome-sequencing-isaiding-vaccines-variant-tracking/

27. https://telecom.economictimes.indiatimes .com/news/pandemic-redefined-ott-spaceonline-gaming-becomes-a-new-sunrisesector/82568329

28. https://www.sba.gov/businessguide/manage-your-business/stay-safecybersecurity-threats

29. https://www.educationconnection.com/res ources/digitaldivide/30.https://news.un.org/en/story/20 20/04/1061592 